\title{
THE DEVELOPMENT OF STUDENTS' MOTIVATIONAL DIMENSIONS UNDER THE PHYSICAL EDUCATION EXPERIMENTAL PROGRAMME
}

Said Hasanbegović ${ }^{1}$

\author{
Mixed Secondary School Banovići
}

Received: 05.03.2014.

Accepted: 04.04.2014.
Original scientific paper

UDC: $37.064 .2: 796$

$373.5: 796$

159.953 .5

\begin{abstract}
This study shows the development of some motivational dimensions of secondary school students when they are treated by the experimental way of teaching. The study was conducted on a sample of 240 pupils of The Secondary School Banovici, out of which 124 males and 116 females. The pupils were divided into two groups. The first group consisted of 120 pupils divided into four sections, out of which 73 males and 47 females. This is the control group. The second group also consisted of 120 pupils divided into four sections, out of which 51 male and 69 females. This group was subjected to the experimental way of teaching and thus represents the experimental group. Results show the changes in pupils' motivational characteristics under the influence of innovative educational content that are reflected through their activities and final attitudes on the physical education value. The discriminate analysis revealed the statistically important differences between pupils that are treated by the experimental program compared to students treated by traditional program in terms of motivation in physical education classes (PE classes). However, the study, in some way, solves the problem of inactivity and pupils' lack of interest for the PE classes, i.e. it suggests the pupils' possible development of motivation for work using the appropriate educational contents.
\end{abstract}

Key words: pupils'motivation, the experimental program

\section{INTRODUCTION}

Considering that there is a noticeable students' motivational decline to PE classes, this study offers the possibilities to develop secondary school pupils' motivation for the classes. It is known that motivation is psychological factor which has the greatest influence on the pupils' activity in PE classes, and thus it is very important to know how to motivate a pupil, and what are the motives that keep them interested in classes and sport.

While analysing pupils' motivation for sport, Suzić (2011) identified three motivational profiles of pupils: with inner motivation, combined motivation and outer motivation. Accepting the fact that students of middle adolescence (from 14 to 18 years) have the greatest difficulties to motivate themselves for school teaching (Suzić, 2006), helps to understand the problem that is being studied. Previous studies indicate the motivators which do not have a common influence on most of the pupils. It is necessary to permanently study the motivation for classes and to take into consideration all the factors that affect its direction, dynamics and character (Muminović, 2000), because without motivation classes are doomed to fail.

\footnotetext{
${ }^{1}$ Correspodence to:

Said Hasanbegović, Mixed Secondary School Banovići

Ulica, OSK. 45. Banovići, B\&H

Phone: +38761705084

E-mail: sajohb@hotmail.com
} 
The experimental program determines what motivates students to be active in PE classes, to work in continuity during the whole school year, the complexity of these motives as well as the reasons for their inactivity. This study will determine the changes of motivational dimensions of pupils who are treated by differently structured curriculums in PE classes, which help pupils to achieve emotional satisfaction. The curriculums are full of games that run various mechanisms in the body and provide the pupils' satisfaction, thus achieving the goals of PE classes. These types of classes made a cosy environment for students in which they could develop their own creativity creating in the end the tasks that they are interested in.

\section{WORK METHODS}

This paper used the discriminate analysis in order to determine the discriminate area which explains the changes in motivational dimensions.

\section{The sample}

The study was conducted on a sample of 240 students of the Secondary School Banovici: 142 males and 116 females. The students were divided into two groups, the first group consisted of 120 students categorized into four sections of 73 males and 47 females; this is the control group. The second group consisted of also 120 students categorized into four sections of 51 male and 69 females, which is subjected to the experimental teaching and thus represents the experimental group.

Independent variable: the motivation of students' achievements

Dependent variable: the experimental program of physical education classes

The instrument: LIMA (The large inventory of motivational achievements) (Pintrich, 2003)

\section{RESULTS AND DISCUSSION}

The discriminate analysis of the attitudes inventory LIMA in the manifest area of measuring in the applied sample

The multi-variant method of the data processing-the discriminate analysis was used to determine the differences between the experimental and the control group of students while studying the motivation for physical education classes. However, even though the discriminate analysis represents a method for deter- mining differences between sub-samples, it can also be used to determine the common features of the respondents through discriminate factor.

This study used the discriminate analysis in order to comprehend the indicators' hierarchy that contribute to the distinction of groups, but it is also used to comprehend the relations between indicators prevailing in the experimental and the control group.

This study used the canonical discriminate analysis which, through determination of indicators, that offer the greatest contribution to the discrimination of sub-samples of the respondents, also defines the characteristics of the groups in the manifest area. In this research, the discriminate area was determined by the discriminate indicators, which are transformed into discriminate functions, while on the other hand, the statistical significance of the discrimination was determined by the F-test (Fisher, 1936).

The discriminate strength of the applied indicator was determined by the Wilks' Lambda, while its significance was tested by the Bartlett's $\chi^{2}$-test. Taking into cosideration that the analysis of the reability showed the reability of measurements on intergroup variance samples of the subjects, the discriminate analysis, on the other hand, isolated its own roots (Lambda) and vectors. The maximization ratio of the intergroup variability marked characteristic roots that show the strength of the discriminate function, and the characteristic root represents a variance of that discriminate function. In this scientific analysis, the standardized discriminate function represents a discriminate factor that points out the scientific conclusion of the gained differences between the experimental and the control group of the applied subsamples, in order to find practical solutions for the motivation in PE classes.

\section{The discriminate analysis of the inventory of atti- tudes in the manifest area of measuring on the ini- tial measuring LIMA}

The significance of differences between the samples of the subjects using the discriminate analysis is being tested by the Wilks' Lambda. Considering that this research belongs to the category of longitudinal study using measuring that are used in two stages (initial and final), in order to determine the difference among the applied groups of subjects, not only by their quantitative characteristics, but also by their changes that occurred in certain period during which the experiment, that was defined by program content for sport motivation, was applied. 
Therefore, the discriminate analysis was used in two cases: in the initial measuring using the quantitative values of the subjects on the applied indicators, thus determining their differences in the final measuring as well, when besides the quantitative differences in the obtained values of the applied indicators, the qualitative distinctions in the changes of subjects' perceptions and relation towards the PE classes, were also determined. In the initial measuring, no statistical significance of the groups' discrimination was determined and Wilks' Lambda was 0.42 with the value of Bartlett's $\chi^{2}$-test of $152.25 . \chi^{2}$-test shows that Wilks' Lambda is not statistically important ( $p$ $=0,007$ ), which indicates that there is no significant differences between the experimental and the control group at the initial measuring of the measured area of sport motivation, i.e. they belong to the equal population characteristics concerning LIMA.

\section{The discriminate analysis of the attitudes inventory in the manifest area in final measuring LIMA}

In final measuring of this inventory, Wilks' Lambda was statistically significant on the level of importance and valued $p=0,000$, whose $\chi^{2}$-test was 334.02, which justifies the applied methods in the scientific elaboration LIMA, i.e.it explains the presence of inventory changes, that happened under the applied experimental program. Cosidering that this paper studies the influence of the experimental way of teaching on the pupils' motivation development in PE classes, the discriminate analysis should explain the quantity and quality of the influence of changes with the help of the discriminate factor. Since there are two groups of subjects, using the logic of the applied method, one discriminate function was singled out, where canonical correlation of the applied indicator system with its isolated discriminate function valued 0.92 .

Table 1. The standardized canonical discriminate function of the idicators on LIMA

\begin{tabular}{lc}
\hline Indicators & Function \\
\hline Self-efficacy & 0,91 \\
Performed self-efficacy & $-0,36$ \\
The perception of competence-recognition & 0,35 \\
Self-valuing & $-0,27$ \\
Engagement & $-0,16$ \\
Control & 0,98 \\
Mastery & 0,68 \\
Performing gaols & 0,31 \\
Non-comformism & 1,43 \\
\hline
\end{tabular}

Considering that LIMA was conceptualized so that certain indicators belong to different motivation areas as psychological dimensions of the human action, the isolated function classified the discriminate characteristics mixing indicators at its own standardized coefficients of dispersive difference, so that it classified indicators by their own dispersive strength thus creating the dispersive root.

Table 2 presents the isolated function of the discriminate coefficients which represent the discriminate area. Considering that LIMA ( $\mathrm{n}=128$ indicators) is created in different motivation areas, the discriminate area is defined through hierarchy of variances that with their greatest variability contribute to the group differentiating and these isolated pedagogicalpsychological dimensions are development carriers of self-valuing, efficacy, control, self-competence and a will for success.

The subjects were not different in the initial measuring, while in the final, their results showed the discriminate dispersion in the sense of motivation. There is no doubt that the experimental program in relation to the LIMA areas, significantly affected students' motivation. Because of this, the scientific explanation to this problem can be found in the variance analysis. 
Table 2. Indicators corelations on the isolated function LIMA

\begin{tabular}{lc}
\hline Indicators & Funkcion \\
\hline Self-valuing & $-0,01$ \\
Self-efficacy & 0,03 \\
Control & 0,01 \\
Chalenge & $-0,00$ \\
Mastery & 0,03 \\
Performed self-efficacy & 0,03 \\
Valuing level of the academic achievements & $-0,03$ \\
Non-conformism & 0,01 \\
Performing gaols & $-0,01$ \\
Self-determination and the academic control & $-0,00$ \\
Engagement & $-0,00$ \\
Interest & $-0,01$ \\
The perception of competention-recognition & 0,00 \\
\hline
\end{tabular}

\section{The variance analysis on LIMA}

In the Table 3 it can be noticed that, in certain cases, the subsamples of the subjects statistically differ in the measuring area of the applied indicators on LIMA. On the level of the applied hypothetical (theoretical) significance of $95 \%, 8$ subareas of indicators, in hierarchical order, singled out according to the following discriminate strength: Self-efficacy, Control, Mastery, Self-valuing, Engagement, Performing gaols, Non-conformism and Perception of competence-recognition. The indicators that have achieved the dis- crimination at the level of significance of $98 \%$ belong to the area of Engagement.

The indicator that achieved the discrimination at the level of significance of $97 \%$ belongs to the area of Performing gaols and Non-conformism, and in the end one indicator that achieved the significance of 95\% belongs to the area of Perception of competence -recognition. Finally, it can be concluded that LIMA was summed up to 8 indicators that, according to the scientific aspect, have appropriate application and value as in praxis so in the theoretical analysis of the students' motivation.

Table 3. The discriminate significance of Wilks' Lambda

\begin{tabular}{lccccc}
\hline Indicators & $\begin{array}{c}\text { Wilks' } \\
\text { Lambda }\end{array}$ & $\boldsymbol{F}$ & Funkcion & $\boldsymbol{d f}$ & $\boldsymbol{p}$ \\
\hline Self-efficacy & 0,47 & 6,64 & 1 & 238 & 0,000 \\
The perception of competence- & 0,97 & 8,05 & 1 & 238 & 0,005 \\
recognition & & & & & \\
Self-valuing & 0,94 & 14,72 & 1 & 238 & 0,001 \\
Engagement & 0,96 & 9,81 & 1 & 238 & 0,002 \\
Control & 0,93 & 18,63 & 1 & 238 & 0,000 \\
Mastery & 0,94 & 13,74 & 1 & 238 & 0,000 \\
Performin gaols & 0,96 & 9,24 & 1 & 238 & 0,003 \\
Non-conformism & 0,96 & 9,03 & 1 & 238 & 0,003 \\
\hline
\end{tabular}


The final discrimination can be mathematically calculated within the applied groups with the help of centroids, which theoretically, stand for arithmetic means of the arithmetic means of the subsamples of the subjects. Table 4 indicates that the experimental group in Gausses coordinate system revealed its centroid on $-2,402$ of the standard deviation; while on the other hand, the control group has a positive centroid, which values 2.402 . It can be concluded that in the measuring space these two groups are distanced from each other for 4.804 of the standard deviation.

\section{Table 4. Groups' centroids on LIMA}

\begin{tabular}{lc}
\hline Groups & Funkcion \\
\hline The experimental group & $-2,402$ \\
The control group & 2,402 \\
\hline
\end{tabular}

\section{CONCLUSION}

In the end, from the findings of this study it can be concluded that the experimental program changed the attitudes of the subjects of the experimental and control group in certain fields that reflect capabilities, understanding, satisfaction because of the achieved results, success, validation and confirmation for the successful work of a student. The results of this study support the assumptions that the specially structured experimental program has a great impact on the students' motivation, which means that the curriculum of the PE classes should be structured in such way to ensure students to fully show their capabilities and to enjoy in classes being aware of their real value. Besides, the results showed that teachers should be more dedicated to classes and that they praise their students for hard work.

These facts suggest that the structure and the curriculum of PE classes should be changed in all secondary schools. This paper explains the problem of students' motivation in PE classes and suggests that their motivation largely depends on the curriculum and other factors that improve the motivational environment in classes. The curriculums should be adjusted to the students' individual capabilities because the level of students' development and capabilities determines the methodical approaches to the classes.

The experimental curriculums positively affected the motivational development of the secondary school students and helped them to find out their own motives and to discover new, unconscious ones that drive them to action. The experimental way of teaching helps to determine types of motives that motivate students, their necessities, their attitudes towards curriculums and their approach to classes. With the help of the experimental work program and servo method, this research determines the students' common motives that drive them to physical activities, as well as the types of curriculums they find interesting and their unconscious motives that affect their positive emotions. It is also expected that they identify the barriers in achieving educational goals.

The results of the study present the real state of students' motivation in PE classes, which can be helpful in further studies of similar subjects and solve other scientific problems.

\section{REFERENCES}

Muminović, H. (2000). Mogućnosti efikasnijeg učenja u nastavi. Sarajevo: Svjetlost.

Suzić, N. (2006). Mjerenje motivacije. Naša škola - časopis za teoriju i praksu vaspitanja i obrazovanja, 3-4, pp. 81-122

Suzić, N. (2006). Unutrašnja i vanjska motivacija u školskom postignuću.Vaspitanje i obrazovanje - časopis za pedagošku teoriju i praksu 4, pp. 289-310

Suzić, N. (2011). Motivacija učenika za sport i njihovo vrednovanje škole. Sportlogia, Naučno-stručni časopis o antroploškim aspektima sporta, fizičkog vaspitanja i rekreacije, 3, pp. 65-84 